\title{
Fast Protein Liquid Chromatography
}

National Cancer Institute

\section{Source}

National Cancer Institute. Fast Protein Liquid Chromatography. NCI Thesaurus. Code C80368.

A type of liquid chromatography where the solvent flow and composition is controlled by pumps. 